\title{
CONSOLIDATING DEMOCRACY IN KOSOVO: THE EFFECTIVE FUNCTIONING OF BASIC INSTITUTIONS
}

\author{
Dr. Sc. Nuredin LUTFIU (i) $1 *$ \\ Dr. Sc. Agon HALABAKU (iD) 2 \\ Valbona FISHEKU-HALABAKU (i) 3 \\ 1 University of Technology and Business "UBT", Faculty of Law, nuredin.lutfiu@gmail.com *Correspondent Author. \\ 2 University of Technology and Business "UBT", Faculty of Management, Economics and Business, agonhalabaku@ hotmail.com \\ 3 SH.M.M.L. "Kongresi i Manastirit", albanafisheku@hotmail.com
}

\author{
Article history: \\ Submission 10 April 2020 \\ Revision 04 June 2020 \\ Accepted 02 July 2021 \\ Available online 31 August 2021
}

\section{Keywords:}

Consolidation of Democracy,

Assembly,

President,

Prime Minister,

Kosovo.

DOI:

https://doi.org/10.32936/pssj.v5i2.235

\begin{abstract}
A b s t r a c t
A democracy is considered to be consolidated when no major political grouping attempts to overthrow the democratic regime or promote violence in order to seize any part of the territory from the existing state. Democracy becomes 'the only game on the town' even when the state faces economic and political difficulties and challenges, all political groups believe and seek to find a solution within the constitutional order and democratic procedures. Namely, before any situation and difficulty in the state, the political forces in the country do not seek to solve problems by undemocratic means.

In addition to the main factors mentioned by various authors, in the case of Kosovo, a key problem for the consolidation of democracy, consolidation and positioning in the international arena is the process of normalization of relations with Serbia and cooperation and effective functioning of the three main constitutional institutions; The Assembly, the President and the Prime Minister of Kosovo, as the main pillars of the system policy based on the principle of separation of powers. In principle, their greatest contribution to the consolidation of democracy in Kosovo is, the election and exercise of constitutional functions is done in accordance with the principles and norms set by the Constitution, enjoys the confidence of the majority of the population in the country, and there are no significant political forces and nor the attitudes of the public trying to replace democracy with authoritarian forms of government. In other words, echoing the metaphorical expression of American scientist Juan Linz, a consolidated democracy emerges when democracy is the only game in town.
\end{abstract}

\section{Introduction}

After a nine-year period of international administration, Kosovo declared its independence in 2008 and since then has held parliamentary and local elections consistently, joining the group of newer Third World democracies. These parliamentary and local elections, considered free and fair in accordance with international standards, further strengthened its legitimacy as a democratic state, with the ultimate aim of consolidating democracy.
Welcoming Kosovo's recent free and fair elections, Zahir Tanin, Special Representative of the Secretary-General and Head of the United Nations Interim Administration Mission in Kosovo (UNMIK) stressed the need to form a new government without delay, resume dialogue with Serbia, and quell the rise in inflammatory nationalist rhetoric (document S/2017/640).

Since then, a cycle of parliamentary elections has begun, and so far four elections have been held. The governments that emerged from these elections did not have long lives. They continue to be short-lived to this day. Without of any exception, no government 
has completed its full governing mandate and has not survived early elections.

In fact, after Kosovo's declaration of independence, there are still many tasks to be fulfilled, conditions to be established, attitudes and habits to be cultivated before the democratic transition phase is completed and its 'maturity' to be assessed as a consolidated democracy. Then, what are the characteristics of a consolidated democracy? Many democracy scholars list a number of conditions and characteristics that a democracy must contain to be considered consolidated. Externally, a democracy can be considered consolidated when no major international entity disputes it in territorial terms or no ethnic grouping within the territory seeks separation from the state. Internally, however, among other things, a democratic regime is established within the territory and no major actors within the state, social, economic, political or institutional make any attempt to establish an undemocratic regime. Thus, when a strong public opinion is created, even amid major economic problems and deep discontent, it is believed that democratic procedures and institutions are the most appropriate way to govern social and political life, i.e. when support for alternative anti-regime forces is too little present or more or less isolated from pro-democratic forces (Linz, Stephan, 1996).

\section{Consolidation of Democracy}

What can certainly be said about democracy is that numerous definitions have been given in order to define it. Aristotle had defined democracy as a form of state regulation whose main characteristic is equality, in which everyone participates in power, but in which the rule of law (Aristotle, 1978, p. 161). What Aristotle's remarks show is that democracy is acceptable to all citizens, since they are elected and can elect their own representatives who govern them, through free and democratic elections held in certain periodic cycles.

Relying on John Adams' definition of democracy, it is rooted in the idea that elected officials should think for the good of the people, feel and reason like him, and often be held accountable for the way they govern (Adams, 2015).

Across countries around the world, democracy is presented in different forms, somewhere it has better representation and a greater expression of freedom, and in other countries it is lacking. Moreover, it is the legislation that properly regulates the exercise of democracy, through the separation of powers, the establishment of control and balance in order to promote equitable distribution of power within the political sphere.
The global developments, namely the modernization and development of the economy of the third world, which was followed by the growth and development of the middle class and its education; changes in the Catholic Church in relation to individual rights; the weakening and disintegration of the Soviet Union, the emergence of the Soviet bloc of leading European countries, their determination for democracy, and the influence of the United States and the European Union in supporting these democracies were among the major factors influencing the creation of the 'third wave of democracy' highlighted by Samuel Huntington in his book "Third Wave: Democratization at the End of the Twentieth Century” (Huntington, 1991).

During this period, many totalitarian regimes in countries around the world have been replaced by democratic systems. While this is a major achievement, problems emerge later in strengthening and stabilizing these new democracies. Because maintaining and developing democracy is as difficult a task as it is to set. In all these democratic transitions, the biggest concerns are how to set up, strengthen and stabilize new regimes so as not to backtrack on totalitarian regimes, now that the spread of democracy in other countries has slowed. This has led political scientists and other actors in new democracies to increasingly focus on using the term "consolidation of democracy" (Schedler, 1998).

In the first phase defined as the transition to democracy we are dealing with the period of establishment of democratic institutions. The main element of this first phase is free elections, where political parties compete for representation in representative institutions after the fall of totalitarian dictatorship. In general terms, this is the stage in which societies embark on the path of transition and create rules that determine how new democratic institutions will function, rules that they then incorporate into their constitutions (Kerasimeonov, 2012).

In essence, the consolidation of democracy is the process of achieving widespread and profound legitimacy, so all important political actors, at both the elite and mass levels, believe that a democratic regime is appropriate and appropriate for them and society as a whole.

As Linz and Alfred Stephan put it, in short, there are three minimum conditions that must be met before we can talk about consolidating democracy:

- Exercising state sovereignty across the state, a functioning state is a condition, 'sine qua non' in modern politics, as free and authoritative elections cannot be held, winners cannot exercise the monopoly of legitimate power and citizens cannot 'protect their rights effectively. 
- Democracy cannot be thought of as consolidated until a democratic transition is made. It is an indispensable, but by no means sufficient, condition for the completion of a democratic transition that requires free and contested elections.

- No regime should be called a democracy unless its rulers govern democratically. If freely elected leaders (no matter the size of their majority) violate the constitution, violate the rights of individuals and minorities, impose legitimate legislative functions, and thus fail to rule within the boundaries of a rule of law, regimes are not a democracy (Linz, Stephan, 1996).

Robert Dahl describes the basic political institutions of representative government in a modern democratic country, pointing out that it only happens in an ideal society, and rarely in current practice, and goes on to say that the existence of a democracy presupposes that all citizens its increased set of fundamental rights, freedoms and opportunities, including:

- the right to vote in the election of officials in a free and fair manner;

○ the right to run for state office by election;

○ the right to free expression;

○ the right to form and participate in independent political organizations, including political parties;

○ the right to benefit from independent sources of information;

○ the rights to any other freedom and opportunity that may be necessary for the effective functioning of large-scale political institutions of democracy (Dahl, 1997).

From this, it can be concluded that elections are the basis of a democratic society through which representative institutions are created, which bear the responsibility to run the state, and with it society, based on the will of the majority of citizens, but this is not all. So it remains that the organization of free and democratic elections and their quality and progress is one of the key points in assessing new and transition democracies. Given this, Kosovo has held credible and relatively well-run elections, but its institutions remain weak, and rampant corruption has caused deep public mistrust in its government (Freedom House, 2020).

In most cases, holding free and democratic elections and fulfilling the basic political institutions of governance required by Dahl takes place, but in a modern democratic country there are still many tasks to be fulfilled for his democracy to be considered consolidated

In the case of Kosovo, in addition to key factors; talks on normalization of Kosovo-Serbia relations, fulfillment of obligations arising from these talks, regional cooperation and development of internal dialogue are one of the main challenges for the consolidation of democracy and critical to all this is the cooperation and functioning of the three main constitutional institutions; The Assembly, the President and the Prime Minister. In this short study, I will address, among other things, the importance of the functioning of these key constitutional institutions; The Assembly, the President and the Prime Minister, in consolidating democracy.

\section{Functioning of key Constitutional Institutions}

The methodology of studying the functioning of the three main constitutional institutions of the Republic of Kosovo will be based on the analysis of the constitutional framework, relevant legislation and decisions of the Constitutional Court, as well as the practice of functioning and cooperation of political parties.

If we focus on the analysis of the literature on the transition to democracy during the Third Wave, we notice that it is focused on internal factors that influence the consolidation of democracy. An important exception is Huntington's Third Wave (1991), in which the author points out that in the consolidation of democracy, external forces can influence decisively.

The elections of October 6, 2019 brought out the Vetëvendosje Movement of Albin Kurti, the first political entity with $26 \%$ of the votes, followed by the Democratic League of Kosovo LDK with about $25 \%$. After the results were confirmed, the two parties began talks on forming a government, which were by no means easy and lasted a long time. Finally, on February 4, 2020, Mr. Albin Kurti was appointed Head of Government. This government lasted only 50 days. The no-confidence motion was sought by the LDK coalition partner, who was unhappy with the way Mr. Kurti was approaching talks on normalizing SerbiaKosovo relations and co-operation agreements with countries in the region.

After that, Kosovo held extraordinary elections, on February 14, 2021. Vetëvendosje Movement came out first, but this time with $50.28 \%$ of the vote.

Election of the government of Mr. Kurti was appointed immediately after the constitution of the Assembly of Kosovo. Following these elections, the election of the president would take place, a post which had remained in office after the resignation of President Thaqi, after the lawsuit was filed by the Special Chambers of the court in The Hague. 
Candidate Mrs. Vjaosa Osmani managed to be elected president after difficult talks with the LDK and the assistance provided by the quint ambassadors, who had supported Kosovo's independence.

The approach of the Kosovo governments to the dialogue for the normalization of Kosovo-Serbia relations seems to have been a measure of their longevity in governance. Since the beginning of these talks, no elected government has been able to complete its full governing mandate, plunging the country into ongoing political crises.

One of the key factors in the consolidation of democracy in Kosovo is the effective functioning of the main state institutions; The Assembly (Kosovo Const. Chapt. IV.), President (Kosovo Const. Chapt. V) and the Government (Kosovo Const. Chapt. VI), which in the Constitution constitutes the main pillars of the political system based on the principle of separation of powers.

The constitution of Kosovo, as a result of the political circumstances of the time it was adopted, was created in view of its main premises, namely the inclusion of the Ahtisaari Package and the maintenance of the separation of powers within the borders of the parliamentary republic.

Amendments to the Constitution of Kosovo, which are considered necessary to complete certain processes in the country, while in principle possible, they still remain practically impossible at present, experts in constitutional legal affairs and political experts in the country say.

The constitution of Kosovo, as the highest legal act of the country, turned out to have many gaps, obstacles that were highlighted during the consolidation of the new state and the efficient functioning of state institutions. The provisions of the Constitution are characterized by contradictions, inconsistencies, ambiguities, ambiguities of concepts and notions as well as terminological omissions which cause great difficulties in the correct interpretation in the implementation in practice (GAP Institution, 2011).

A small number of changes have been made to the Constitution in order to round out certain processes in place. Some others, while possible in principle, still remain virtually impossible at present as a result of the adjustments within the constitution itself. In general, these changes relate to the following aspects: The transformation of the Kosovo Security Force, into the Kosovo Armed Forces or changes to the electoral system in the country, but others, remain hostage to the hitherto impossibility of constitutional change.
At the same time, Kosovo's main institutions are facing a number of challenges in exercising their constitutional functions, causing confidence in them to diminish in Kosovo's public opinion and society.

Assembly of Kosovo - The main representative institution, since the 2014 elections, has begun to face the decline of confidence it should enjoy. During the year, he faced a six-month blockade that hampered its constitution and the exercise of its basic constitutional functions. It was only after the judgment of the Constitutional Court that he succeeded in constituting and continuing the exercise of his mandate functions, without being able to complete his full mandate. An almost similar situation arose after the 2019 extraordinary elections, where its organs were created following a procedure questioned by the opposition, with the tendency that the procedure for the election of the top assembly would once again be referred to the Constitutional Court.

Members of the Assembly of Kosovo fail to perform their main function of lawmakers in the name of the common good. Their legislative activity is mainly driven by private interests, they are barricaded against group and party interests and there is no concession on the key issues. The ruling coalition has had limited success in pushing ahead with EU reforms and building consensus on key strategic issues for Kosovo, but continued political fragmentation and polarization have negatively affected the role of the Assembly and affected the effectiveness of the government. Frequent absence of parliamentarians from plenary sessions and continued political polarization hampered the legislative activity of the assembly, in particular due to the irresponsible behavior of some parliamentarians involved in the use of tear gas to obstruct the work of the Assembly (Commission Staff Working Document Kosovo, 2018).

The exercise of the Assembly's political control over the Government, in the capacity of the supreme body of representative power, in fact remains one of its most significant weaknesses. This comes as a result of the party's strict discipline over its MPs and the executive's determination to impose its will. This is the main reason why one of the main functions of the Assembly, which is to exercise its parliamentary control over the government, is not playing its role of a corrective for the executive's actions to the extent necessary and sufficient.

The President - Parliamentary systems, such as that of our country, usually have the functions of the President of the State and the Prime Minister or the Head of Government. The duties of the president of the state are usually to represent the country, 
perform ceremonial duties as an embodiment of state authority, and provide civic leadership as an expression of state identity.

Under the Kosovo Constitution, the post of president is largely a ceremonial post (Kosovo Const. art. V, par. 3), the fact that the president lacks credibility to intervene during political crises and is seen to carry luggage and bias towards the political party, and this seriously weakens institutional controls and balances.

Pursuant to Article 4 paragraph 3, it is emphasized that the role of the President of the Republic of Kosovo is not endowed with executive powers, i.e. he is a symbolic leader of the state who plays a representative role at home and abroad and does not exercise executive power (Kosovo Const. art. V. par, 3,4).

However, the President of the Republic of Kosovo may possess and exercise certain discretionary powers that may be associated with certain political interference as an arbitrator or constitutional guarantor, which will be dealt with in this study.

Moreover, the President of Kosovo is a guarantor of the democratic functioning of the institutions of the Republic of Kosovo, in accordance with the constitution and is a permanent representative of the state. Its role can provide additional continuity and stability to the state, enable more inclusive representation, act as a figure of national unity, and can moderate political conflicts.

The procedure for the election of the President of the Republic of Kosovo is regulated by the Constitution of Kosovo and LAW NO. 03 / L-094 ON THE PRESIDENT OF THE REPUBLIC OF KOSOVO.

Since the first post-war parliamentary elections (2001) to date, Kosovo has had five presidents. Their election has been marred by institutional crises and numerous political bargains, and the Constitutional Court has 'cared' for the termination of both of them, whose judgments remain controversial today (KDI, 2015).

The first President of the Republic of Kosovo was Mr. Fatmir Sejdiu, from the Democratic League of Kosovo. He was elected to the post after three rounds of voting, with 80 votes in favor, 12 against and 17 abstentions, on February 10, 2006 (Kosovo Const. Art. 91, phar. 1,2,3).

$\mathrm{He}$ failed to complete his mandate after he stepped down as president on September 27, 2010, following a Constitutional Court ruling that found Sejdiu had committed a serious violation of the Constitution by holding the post of president of the
Democratic League of Kosovo and the President of Kosovo, though the post of DLK chairman was frozen.

Following the resignation of Mr. Sejdiu, from the post of President of Kosovo, in order not to cause institutional vacuum, the Acting President until the election of another candidate, was appointed Mr. Jakup Krasniqi, who was from the Democratic Party of Kosovo, was in the position of Speaker of Parliament.

On February 21, 2011, the Assembly of Kosovo elected President, Mr. Behgjet Pacolli from the New Kosovo Alliance party. This decision of the Assembly of the Republic of Kosovo, at the request of Sabri Hamiti and some other Members of Parliament, was overturned by the Constitutional Court of Kosovo in its decision, 'Clarification of Judgment in Case no. KO 29/11 (Constitutional Court, KO 19/11).

On February 21, 2011, the Assembly of Kosovo elected President, Mr. Behgjet Pacolli from the New Kosovo Alliance party. This decision of the Assembly of the Republic of Kosovo, at the request of Sabri Hamiti and several other deputies, was overturned by the Constitutional Court of Kosovo in its decision, 'Clarification of Judgment in case no. KO 29/11 (Constitutional Court, KO 29/11).

Following the Constitutional Court's decision, on 4 April 2011, Mr. Behgjet Pacolli resigned from the post of President of Kosovo. This post was held for the second time by Mr. Jakup Krasniqi, President of the Assembly of Kosovo. He was first appointed to the post last year, following the resignation of President Sejdiu.

This court, in its judgment, declared the decision of the Kosovo Assembly of 21 February 2011 to appoint Behgjet Pacolli as President unconstitutional and declared it invalid as of March 30. According to her, the 34 deputies of the Democratic League of Kosovo (DLK) and the Alliance for the Future of Kosovo (AFK) were entitled to the submission, because voting in the session did not have the proper quorum (two-thirds of the Assembly total) and there was also no opposition to Pacolli - as prescribed by the procedure for electing the president, which violated the country's Constitution (Constitutional Court, KO 29/11).

Atifete Jahjaga was the joint candidate of DPK, DLK and ANK Alliance for New Kosovo, based on the agreement reached between the leaders of these three political parties, under the mediation of the US ambassador to Pristina, Christopher Dell.

On April 7, 2011, with 80 votes in favor, the Assembly of Kosovo elected former Kosovo Police Deputy Director General Atifete 
Jahjagan to the post of presidents, while her deputy, ANK Member of Parliament, Suzana Novobërdaliu, received only 10 votes, 10 more were invalid.

Hashim Thaçi is President of the Republic of Kosovo, elected on February 26, 2016 in the Assembly of Kosovo. He was elected President of Kosovo, with 71 votes, only after the third round of voting in the Assembly, following the failure of the first and second rounds of his election as president.

The process of electing Mr. Thaci for president in the Kosovo Assembly was followed by dramatic events. In the Assembly, the process of voting for the new presidency continued with only 83 MPs present after the opposition was expelled from the session after numerous violent tear gas incidents.

Opposition supporters, meanwhile, began clashes with police, throwing Molotov cocktails at them. Meanwhile, police responded with tear gas and pressure water (Gashi, 2016, 26 February).

Executive power is exercised by the Government, with the Prime Minister in charge. After 2008, elections were held for the Assembly of Kosovo, where the Democratic Party of Kosovo emerged as the most voted.

After 2008, different types of governments were formed, but none of these governments succeeded in completing their full mandate. Thus, during this period, we can speak of an unstable situation with regard to the executive.

Already in the first phase there were allegations of election fraud, leading to a repeat of elections in a number of constituencies, resulting in the formation of a coalition between the PDK and the $\mathrm{AKR}$, as well as a number of smaller parties. The agreement to form a government between the two parties included a powersharing agreement, where the leader of the New Kosovo Alliance, Mr. Pacolli would be elected President and Thaçi would continue as Prime Minister (KDI, 2018).

After the Constitutional Court found that the election of $\mathrm{Mr}$. Pacolli as president was irregular and unconstitutional, due to the lack of necessary quorum in parliament during the voting procedure (LDK and the rest of the opposition boycotted the session during which Pacolli was elected), the ruling coalition did not break down, as Mr. Pacolli was elected Deputy Prime Minister.

The discontent over the functioning of the government began as a result of a number of failures on the national front (visa liberalization with the EU) and the start of negotiations on normalizing relations between Serbia and Kosovo, with EU support. The engagement of Prime Minister Thaçi and PDK in these negotiations led him to become less and less engaged in governing the country together with the coalition. At the same time, allegations of corruption and abuse at high levels of government were increasingly spread by opposition, independent media, international actors and nongovernmental observers, further damaging the seemingly broad base of popular support that PDK enjoyed in 2007 (KDI, 2018).

Although the exact motives for Thaci's decision to disrupt the coalition and call for early elections are not known. At this time, from his behavior and that of the DPK, it was clear that the continuation of the coalition with Pacolli and New Kosovo Alliance Party was considered politically harmful (KDI, 2018).

The circumstances that led to the creation of the Mustafa government in 2017 were the circumstances that arose after the Kosovo Assembly elections. Following the announcement of the final results of the elections held on June 8, 2014, according to the publication of the Central Election Commission, the Democratic Party of Kosovo - PDK, together with the smaller parties in the coalition, received 222,181 votes or $31.38 \%$ and as such was the winner in this election.

Opposition parties, the Democratic League of Kosovo LDK, the Self-Determination Movement - LVV, the Alliance for the Future of Kosovo - AAK and the Initiative for Kosovo, formed a postelection coalition, then known as the VLAN, stating that they had a majority in the Assembly and were aiming to win the post of President of Parliament and the formation of the government. A coalition that has kept political and social life locked up for more than six months and only after the Constitutional Court's ruling came to this unblocking.

The PDK-LDK coalition was created in 2014, after a long period of institutional blockade and uncertainty created after these elections. The creation of the 'Mustafa Government' appeared to have come as a result of bargains and negotiations with many unknowns, which led to the emergence of subsequent crises that aggravated Kosovo's political life and directly influenced the consolidation of its democracy.

In 2016, Thaci left the government, where he had served as deputy prime minister and minister of foreign affairs, to become President. 
In 2016, Thaci left the government, where he served as Deputy Prime Minister and Minister of Foreign Affairs, to become President.

The PDK President, Mr. Kadri Veseli, who held the post of Speaker of the Assembly of Kosovo, had an important role in his party, but not in the 'Mustafa Government'. In early 2017, he began a series of conversations with citizens to hear their concerns about the work and direction of government. Mr. Veseli's tour later resulted in a no-confidence motion against the government in Parliament, which passed with the support of all opposition parties as well as DPK MPs, leading to the fall of the Mustafa government, making it go once again early elections.

Although the 2017 parliamentary elections brought about a major electoral overthrow, as the Vetevendosje Movement emerged as the most voted party in the party plan, they failed to influence the creation of a new government. The so-called PAN Coalition, consisting of PDK, AAK and Initiative for Kosovo, won the elections.

Only three months after the June 11th elections, this coalition managed to form the new government and Kosovo to have its own government. On September 9, this winning PDK-AAK-NISMA coalition became possible only after the support given by Behgjet Pacolli's New Alliance for Kosovo (AKR) Party, and all minority MPs including the Serbian List. Sixty-one of the 120 members of the assembly voted for Ramush Haradinaj's cabinet. With a small majority, against a very strong opposition, Haradinaj's government could only survive until June 2018. When Haradinaj told the media and coalition members the reason for his resignation, he said that he had received the resignation invitation from the Special Court, in the capacity of a suspect, although there were no reports as to whether an indictment had been filed against Haradinaj (Fokus, 2019, 19, june).

Weaknesses in the exercise of government have emerged in all government mandates, from the first, the Thaqi government to the last, Haradinaj. These governments were unable to overcome the ongoing internal tensions within the coalitions created by the hostility of the parties within it. The internal contradictions and short time of governance made them never fulfill their government program. "Moreover, the complexity of political bargaining - with office control, the main object of such talks has also led to a rapid increase in the number of parties in government, the number of deputy prime ministers, the number of cabinet ministries, and the number of deputy ministers. With the current government of twenty-one ministers, the small country of two million inhabitants boasts a larger cabinet than Germany's" ((Fokus, 2019, 19, June).

\section{Conclusions}

The challenges that Kosovo faces in consolidating democracy are many and varied, including the ongoing process of state-building that requires the engagement of the entire political elite, whether in opposition or in government, for radical reform. Harmonious and adequate functioning according to the constitutional provisions of the basic state institutions, adequate choice of policies in a context where democratic norms do not suffer from the opposition of individuals to use the lack of adequate constitutional remedies in the creation of individual authority. Despite an advanced degree of democratic stability that has been booming in recent years, it cannot be said that Kosovo has met the conditions necessary for the consolidation of democracy. Perhaps, what can be said for sure is that Kosovo has successfully passed the stage of democratic transition.

The performance of these three institutions should focus on removing the difficulties and problems described above, trying to make their competencies work, harmonizing efforts to ensure a strong rooting of democratic governance, in the country's political landscape at all levels.

Particular attention should be focused on co-operation and harmonization of actions between these democratic institutions, enhancing institutional capacity to adapt with the social forces that lead to the development of the country.

As the consolidation of democracy depends on the exercise and empowerment of these institutions, the deepening of institutional cooperation is crucial in making important decisions for the state, in the ultimate control of decision-making by complementing and balancing adherence to international standards and recognized procedures as well as has a greater response to local values and forms of political legitimacy.

The arguments presented above, which in many cases are part of the public debate, I believe, are sufficient evidence that basic constitutional institutions are failing to perform their key constitutional functions in the name of the common good. Their constitutional activity often transcends the interests of the individual himself and the political groups of origin, despite pressure from local and international public opinion. The progress report presented by the European Commission states that the Assembly should substantially improve its work as a forum for constructive dialogue and political representation, but also to ensure proper checks and balances. Furthermore, the Assembly lacks the powers and capacity to effectively oversee the agencies / bodies reporting directly to it. In most governments, as was the case in the latter, in 2017, the political parties created coalition governments with national priority EU integration and other international institutions. But instead of realizing the national priorities presented, it came to the division of spheres of influence between the ruling coalition, which directly affected the weakened position of the Prime Minister in the capacity of person 
in charge of the Cabinet on the one hand, and the encouragement of corrupt practices within the particular government spheres on the other hand. The end of government in 2019 was characterized by disagreements between the Prime Minister and the Speaker of Parliament, who was the leader of the largest party in government, which contributed to the destabilization of the political process in the country which led to the holding of extraordinary elections.

\section{References}

1. Aristoteli. (1978). "Politika" (Politics). Rilindja. Prishtinë Rilindja.

2. Bajrami, A, (2011). "Sistemi Kushtetues i Republikës së Kosovës”. Artini Publication House. Prishtinë.

3. Democratic Institut of Kosovo. (2015). Election of the President by the people need or rhetoric. https://kdi-kosova.org/en/publications/election-ofthe-president-by-the-people-time-need-or-usualrhetoric/

4. Gashi F., (2016, February 26). Hashim Thaçi zgjidhet President i Kosovës në raundin e tretë me 71 vota. Available at https://www.gazetashqip.com/2016/02/26/hashim-thaci-zgjidhetpresident-i-kosoves-ne-raundin-e-trete-me-71-vota/

5. Gjykata Kushtetuese (Constitutional Court) "Sqarimi i aktgjykimit në Rastin Nr. KO 29/11”. Available at https://gjk-ks.org/wpcontent/uploads/vendimet/gjkk ko $29 \quad 11$ shq.pdf

6. Huntington, S. (1991). The Third Wave: Democratization in the Late Twentieth Century, University of Oklahoma Press.

7. In Democracy for Development Institute: (2018). Kosovo's democracy at risk? Party system volatility, government duration and institutional crisis in Kosovo. Available at https://d4d-ks.org/wpcontent/uploads/2018/05/D4D_Elections 11_ENG_ WEB.pdf

8. Adams, J. (2015). The Works of John Adams. Vol. 4: Novanglus, Thoughts on Government, Defence of the Constitution (Altenmünster, Germany: Jazzybee Verlag). Available at https://www.amazon.com/Works-John-Adams-VolConstitution/dp/3849693856

9. Dahl, R. (1997). Toward Democracy: A Journey, Reflections: 1940 - 1997, volume one (Institute of Governmental Studies Press: Universidad de California). Available at http://www.gbv.de/dms/subhamburg/248206672.pdf
10. Linz, J.J. and Stephan, A. (1996). Toward Consolidated Democracies, Journal of Democracy 7 , 2 (April 1996), 14 33. Available at http://adpm.pbworks.com/f/Democratic\%20Consolid ation-Linz\%20and\%20Stepan-1996.pdf

11. Schedler, A. (1998). What is Democratic Consolidation? Journal of Democracy Volume 9, Number 2, April 1998, 91-107. https://doi.org/10.1353/jod.1998.0030

12. In Report of the Secretary-General on the United Nations Interim Administration Mission in Kosovo (UNMIK). S/2017/640. Available at https://www.securitycouncilreport.org/atf/cf/\%7B65 BFCF9B-6D27-4E9C-8CD3CF6E4FF96FF9\%7D/s 2017 640.pdf

13. Freedom House 2019 Kosovo Electoral Process. Available at https://freedomhouse.org/country/kosovo/freedomworld/2019

14. European Commission, "Kosovo 2018 Progress Report”, Brussels. Available at https://ec.europa.eu/neighbourhoodenlargement/sites/near/files/20180417-kosovoreport.pdf

15. Karasimeonov, G. (2012). Challenges Facing the Consolidation of Democracy in Bulgaria. Friedrich Ebert Fondation. Available at https://library.fes.de/pdf-files/bueros/sofia/09391.pdf

16. Instituti Demokraci për zhvillim (Democracy Institute for Development). (2018). Demokracia e Kosovës në rrezik?. Available at https://d4dks.org/wp content/uploads/2018/05/D4D Elections 11 SHQ WEB.pdf

17. Kushtetuta e Republikës së Kosovës (Constitution of the Republic of Kosovo) Chapter IV, V and VI. Available at https://gzk.rksgov.net/ActDetail.aspx?ActID=3702

18. Shehu B., (2019). Ramush Haradinaj jep dorëheqje të parevokueshme, Fokus, Kosovë. Available at https://www.dw.com/sq/kosov\%C3\%AB-ramushharadinaj-jep-dor\%C3\%ABheqje-t\%C3\%ABparevokueshme/a-49655224 